\title{
GLL
}

Geomatics, Landmanagement and Landscape No. $1 \bullet 2021,81-91$

\section{ANALYSIS OF THE STATE OF PRESERVATION, SPATIAL ARRANGEMENT AND TOURIST USAGE OF RESIDENTIAL AND GARDEN PREMISES IN JANÓW (SILESIAN VOIVODESHIP, POLAND)}

\author{
Michał Uruszczak
}

\begin{abstract}
Summary
The aim of the study is to analyse and evaluate the state of preservation of residential and garden premises and their current use in the Janów commune (Silesian Voivodeship, Poland). The commune, having a huge landscape and natural potential, has at the same time four palace and park premises that are listed in the Registry of Objects of Cultural Heritage. They are located in: Bystrzanowice-Dwór, Czepurka, Złoty Potok and Żuraw. The objects' history, current state and tourist potential, resulting from their presence in the commune, are presented. Tourism, as a tool of regional policy, facilitates professional insertion of local community. It also influences the region in terms of nature conservation, landscape quality and attention to monuments.
\end{abstract}

\section{Keywords}

Janów • tourism • residential and garden premises • Kraków-Częstochowa Upland

\section{Purpose, subject and scope of the study}

The purpose of the study is to analyse and evaluate the current state of spatial arrangement of residential and garden premises in the Janów commune. The selected premises come from various eras and, as already mentioned, are located in the following towns: Bystrzanowice-Dwór, Czepurka, Złoty Potok and Żuraw. The final result is a comparative analysis and presentation of problems related to the facilities. The four significant residential and garden premises in the Janów commune may become a reason for the creation of a local manor trail, or at least to the enrichment of existing ones. The study will facilitate the consideration of the rightness and possibilities of implementing such an idea. 


\section{General characteristics of the Janów commune}

The Janów commune is located south-east of the city of Częstochowa. The greater part is located on the Częstochowa Upland, and its north-eastern part on the Lelów range. The area of the commune has an exceptionally varied topography. It is characterised by the presence of many hills and limestone outliers [Zwoliński 1992, p. 5]. The name of the village of Janów comes from the name of its founder, Jan Aleksander Koniecpolski, who influenced its development in the 17th century [Rymut 1967, p. 63].

An important factor conditioning the nature and influencing the development of, among others, tourism in the commune, are three valleys within its borders, converging in the Złoty Potok depression, as well as the Wiercica river flowing between them, around which a settlement has developed. In the commune, there are also well-known springs, e.g., the Spring of Fulfilled Dreams and the Zygmunt Spring.

\section{Residential and garden premises of the Janów commune}

Bystrzanowice-Dwór is a town located within the so-called Gorzków Mountains, whose highest elevation reaches $380 \mathrm{~m}$ above sea level. The village is surrounded by a forest called Malinik and the Bukowa Kępa reserve [Snoch and Podobiński 2001, p. 34]. The name of the village comes from the manor house on its edge, built by the Raczyński family, owners of the Zloty Potok manor. Originally intended for the former property manager, it began to crumble at the end of the 20th century. The facility 'took part' in World War II, as it acted as a shelter to partisans, incl. Jerzy 'Ponury' Krupiński's unit. Parachute drops for Home Army units also took place near the manor [Siwiński 2009, p. 40].

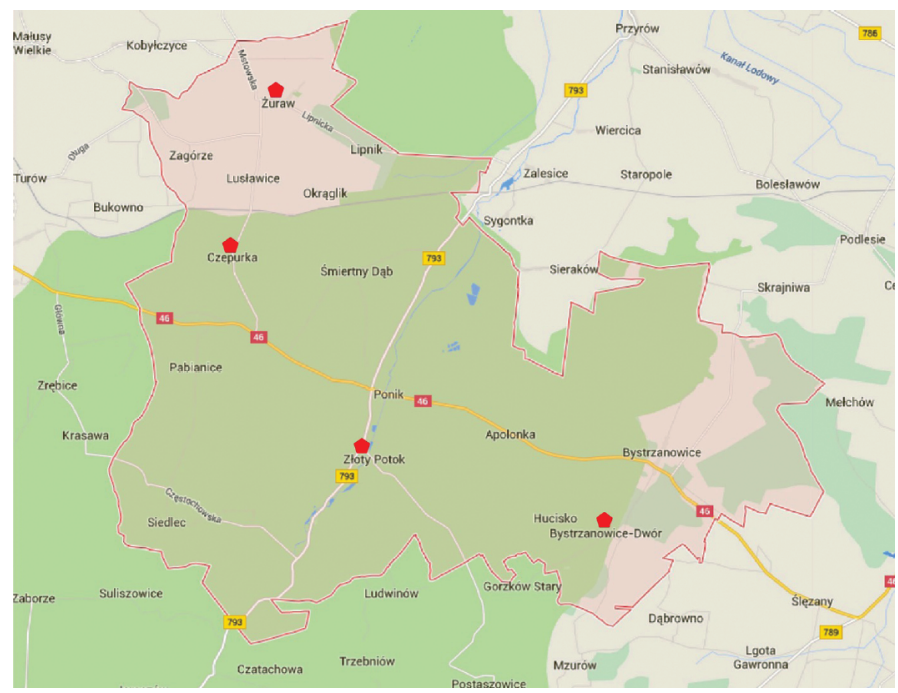

Source: Author's own study based on: https://www.google.pl/maps/place/Janów

Fig. 1. Arrangement of the described objects in the commune area 


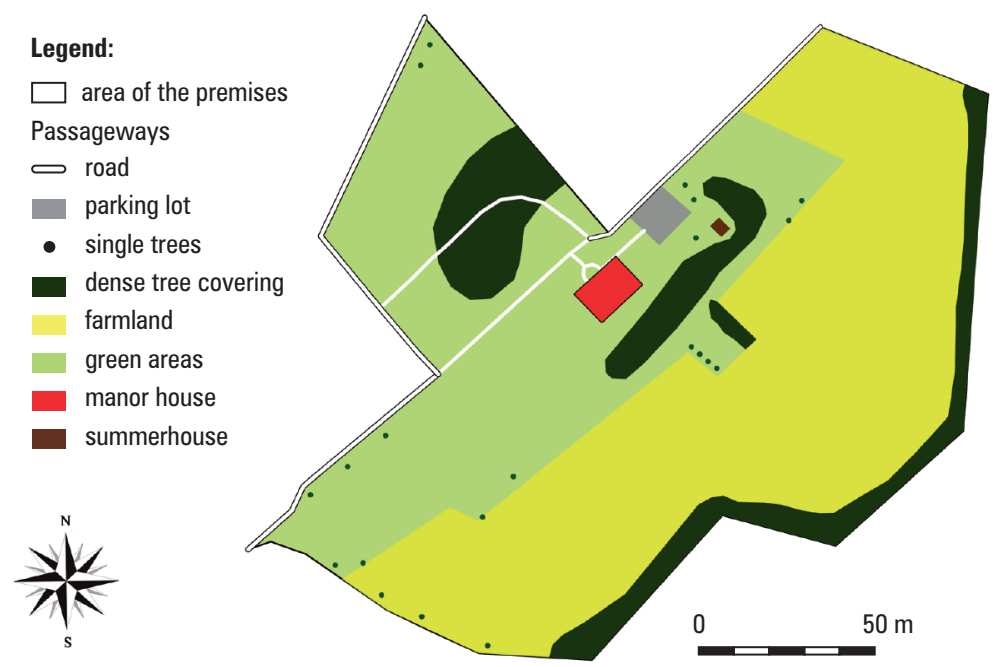

Source: Study by K. Banajska 2015

Fig. 2. The whole spatial arrangement of the Bystrzanowice-Dwór manor

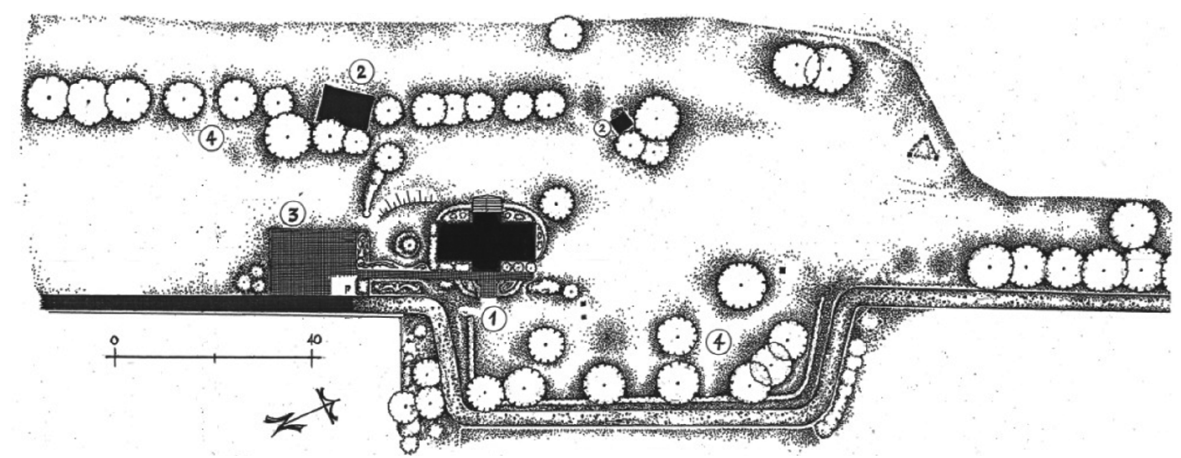

Source: Study by M. Uruszczak

Fig. 3. Bystrzanowice-Dwór. 1 - front part in front of the manor house, incl. the garden floor, 2 - recreational buildings (roofing, summerhouse), 3 - parking lot, 4 - the oldest vegetation. As of 2013

The preserved composition of the manor is related to the lane arrangement of historical trees, located mainly on the north-south axis. They are related, among others, with the access road to the building and the ground decline on its eastern side. In the vicinity of the rebuilt manor house, i.a. a parking lot, small plots of roses and trimmed hedges, and additional elements of small garden architecture, such as a summerhouse or a special roofing were introduced. The connection of the establishment with the surrounding green areas (including the aforementioned Gorzków Mountains), apart from the presence of high voltage pylons in the garden area, remains undisturbed at 
the moment. It can therefore be assumed that the creators' idea of locating the object in the specific scenery of the Gorzków Mountains, surrounded by nature, has not changed since its construction.

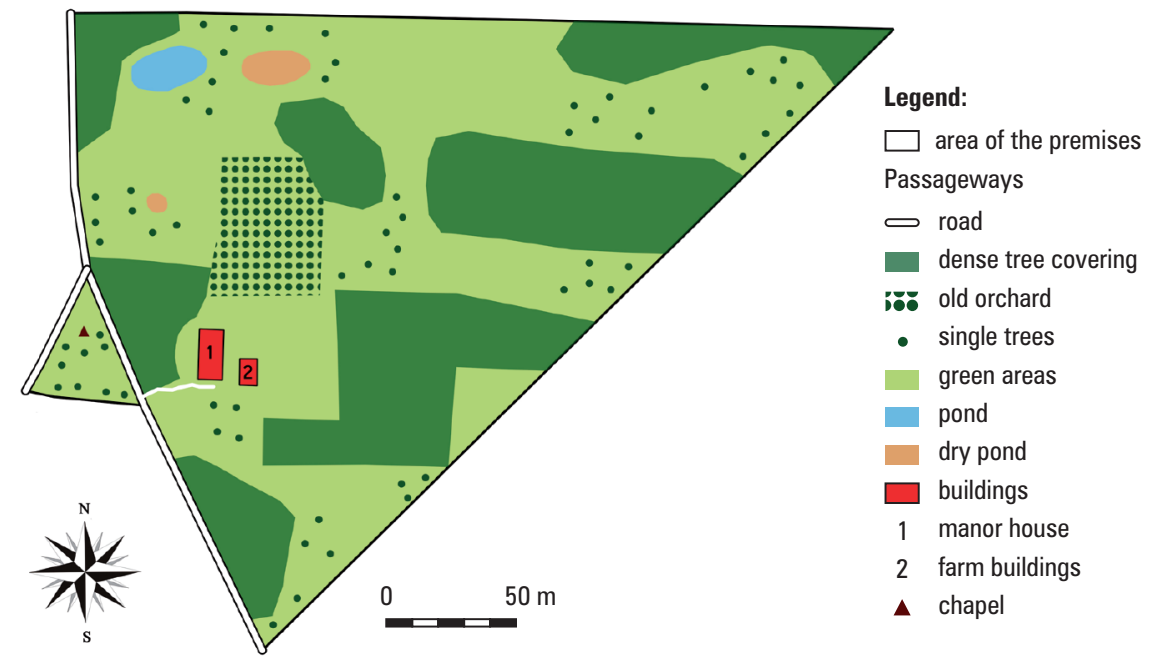

Source: Study by K. Banajska 2015

Fig. 4. Spatial arrangement of the whole domain area in Czepurka, the Janów commune

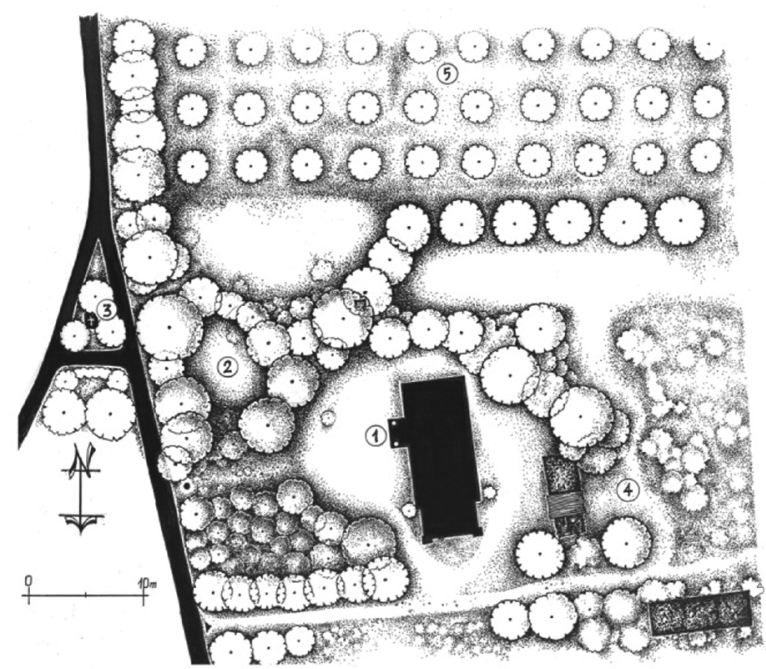

Source: Study by M. Uruszczak

Fig. 5. Closest surroundings of the manor house in Czepurka. As of 2013. 1 - manor house, 2 - historical vegetation, traces of the original composition, 3 - crossroads with a chapel, 4 - outbuilding part built-up with primitive objects and roofs, 5 - orchard 
Czepurka, the second of the four villages of the Janów commune known for the presence of a historic manor and park, was part of the Złoty Potok manor, belonging to the Krasiński and then Raczyński families. At the beginning of the 20th century, the manor area existing since the 19 th century was parcelled out. The reason was the reform of the Potocki family domain carried out by K. Raczyński. It was then decided that it was necessary to raise the standard of the manor house in the village. At that time, an 8 -meter wing was added to the west, where a living room overlooking the garden was arranged. On the eastern side, a glass veranda with an entrance to the garden was built. In front of the house, an oval driveway with various roses was created. During World War II, the Allied landing troops took refuge in the manor [Majer 1992].

The current, unfavourable looks of the park is the result of many years of neglect. Only the front part remains legible, with the outline of an oval driveway in front of the manor house. Numerous tall self-seedings somewhat 'integrate' with the original ornamental vegetation. The arrangement of the premises as a whole seems to be a remnant of the original design, with the present and legible orchard and ponds. The manor house itself is in a bad condition It has been uninhabited for years, surrounded by temporary buildings.

Złoty Potok is a palace and park complex with an area of 35 hectares, from the turn of the 19th and 20th centuries [Bartman et al. 1992, p. 58]. It is an extensive landscape complex designed by Franciszek Szanior, with a large pond, numerous alleys with preserved old and valuable trees [Samek-Rejduch and Samek 1979, p. 36]. It belongs to the group of large residential and garden complexes [Bogdanowski 1982, p. 19].

Count K. Raczyński decided to create a spectacular family residence. The composition was based on several essential elements, such as the Wiercica river, an interesting terrain configuration and an existing old tree stand. To the left of the main entrance to the park, an orangery was established; it does not exist any longer, only a small hexagonal brick structure with a barrel-vaulted cellar remains. Right next to a four-apartment residential building for the farm service, there was originally a water turbine, which, together with over 100 batteries, supplied the palace and the buildings belonging to the complex with the necessary electricity. The choice of the site for the project was influenced by the considerable variation in the height of the park area: from $270 \mathrm{~m}$ a.s.l. in the north-west to 300 a.s.l. in its eastern part. Due to the varying degree of ground humidity, almost the entire area is covered with mixed stands. The exception is the vast northern part of the park, where the soil conditions are very humid, with alder riparian forests. This part of the premises, being wet, is relatively rarely visited, in contrast to the unique southern part of the park, where Szanior introduced a number of species rare in Poland. Worth mentioning, among others, are the Canadian hemlock, red oak and common oak (the hanging variety), American basswood, Japanese larch, western yellow-pine, Weymouth pine, American tulip tree, field elm (the Dampler variety) and Siberian elm (the Turkestan variety) [Zwoliński 1992, p. 26-28].

The park has a trapezoidal shape along the north-south axis. It is surrounded by a wall of limestone. It is adjacent to fields and various farm buildings connected with the manor. The picturesque natural landscape surrounding it, by its nature containing 
numerous distinctive peculiarities, such as groups of old trees, rocks, hills, has been arranged as a 'park landscape' [Ciołek 1978, p. 185-187]. It was reinforced by landscape arrangements, such as the creation of a three-row avenue between the palace and the nearby church, on the initiative of Karol and Stefania Raczyński. It was lined with maples and chestnuts [Siwiński 2009, p. 51]. It is integrated with the park itself, where we can also find avenues of trees of impressive size. Species that can be seen are maple and birch [Zwoliński 1992, p. 27].

The Złoty Potok Park is also adjacent to the Trail of the Eagle's Nests. Nearby are, among others, the watchtower in Lutowiec and Ostrężnik castle [Uruszczak 2003, p. 187-210].

In 1948, the Secondary Agricultural School was located in the palace, which was renamed the Four-Year State Agricultural Secondary School a year later. J. Perczak was its first head teacher. In the seventies, after the construction of a new complex in the north-eastern part of the premises, the school was moved from the palace [Zatoński 2010, p. 12-17].

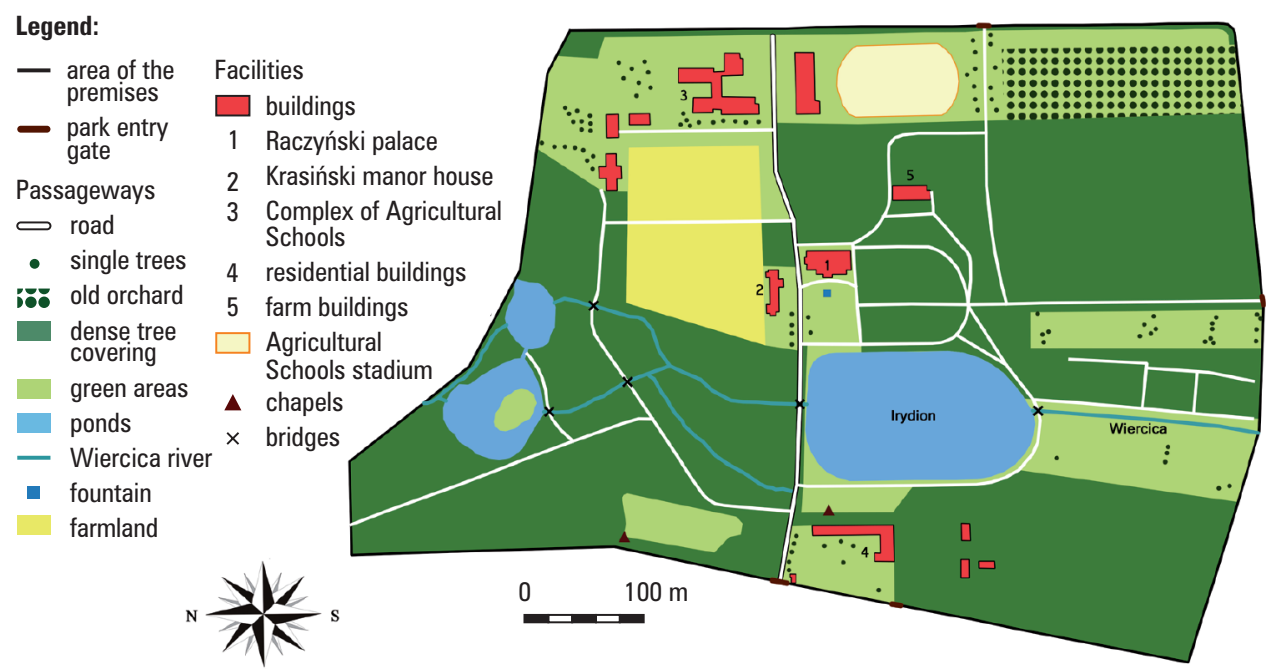

Source: Study by K. Banajska 2015

Fig. 6. The Złoty Potok Park area. As of 2015

The terrain is slightly undulating. The Wiercica River flows through its centre from the south to the north, originating from the Zygmunt and Elżbieta springs, which are about $4 \mathrm{~km}$ away from the park. In its central part, there is the largest pond among the numerous ponds in the park, named 'Irydion'. Its waters were dammed thanks to the artificial cascade on the river Wiercica. To the west, there is a statue of the Mother of God. Set on a pedestal with the Raczyński and Czetwertyński coats of arms, it was created in 1912 and commemorates two deceased children [Siwiński 2009, p. 53]. 
Behind the cascade, the river branches into two separate watercourses, flowing into separate ponds in the northern part of the park [Kowalewski 1989, p. 58].

The present front gate, embedded in a stone wall, replaced the original one, forged from iron, looted and taken to Germany during World War II. It opened up a panorama of the park and two manor houses within it. For beside the main palace, on its left side there is a classicist wooden manor house built in 1829, which has been functioning as the Zygmunt Krasiński regional museum since 1987. A brick, classicist palace was built in 1856 by Wincenty Krasiński. Unfortunately, the name of the project architect could not be determined [Borowska-Antoniewicz and Jakubowski 1980, p. 8]. It is twostory in its central part, and has a driveway to a spacious observation deck based on 6 pillars, with sculptures of two lions standing next to them, holding shields of coats of arms. There is a fountain in the centre of the driveway [Siwiński 2009]. The palace part is the most legible part of the analysed area, being kept in the best condition.

The premises in Zuraw are located in the centre of a small village, first mentioned in 1220 [Rymut 1967, p. 206]. It was related to the existence of a residential and defence tower in this place, surrounded by an earth embankment [Siwiński 2010, p. 3].

The manor house is from the 18th century. It was rebuilt in 1914 by K. Raczyński. Gradually, the building deteriorated, becoming devastated, especially after World War II. Then in 1989 the building was sold to private owners and 5 years later it was renovated under the supervision of the conservator of monuments.

The most legible part of the park with an area of 3 ha is the vast part of the open view to the south. On the eastern side, a pond is visible beyond the fence. This object is located very close to the premises in Czepurka.

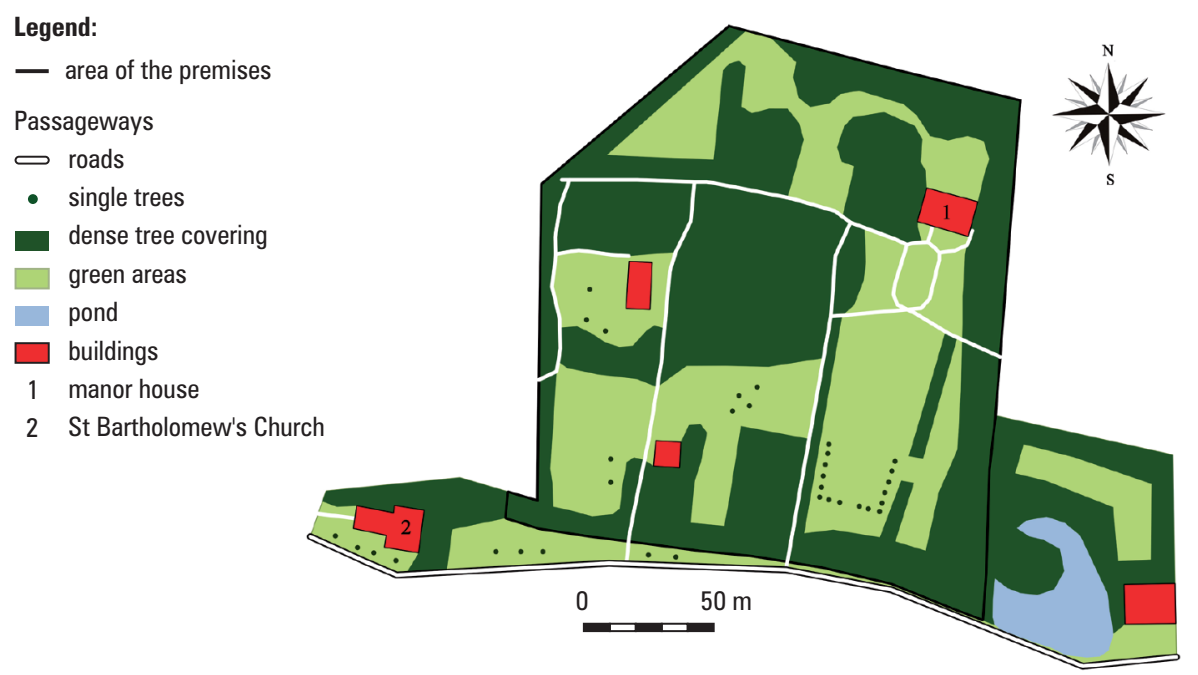

Source: Study by K. Banajska 2015

Fig. 7. The arrangement of the residential and garden premises in Żuraw in 2015 


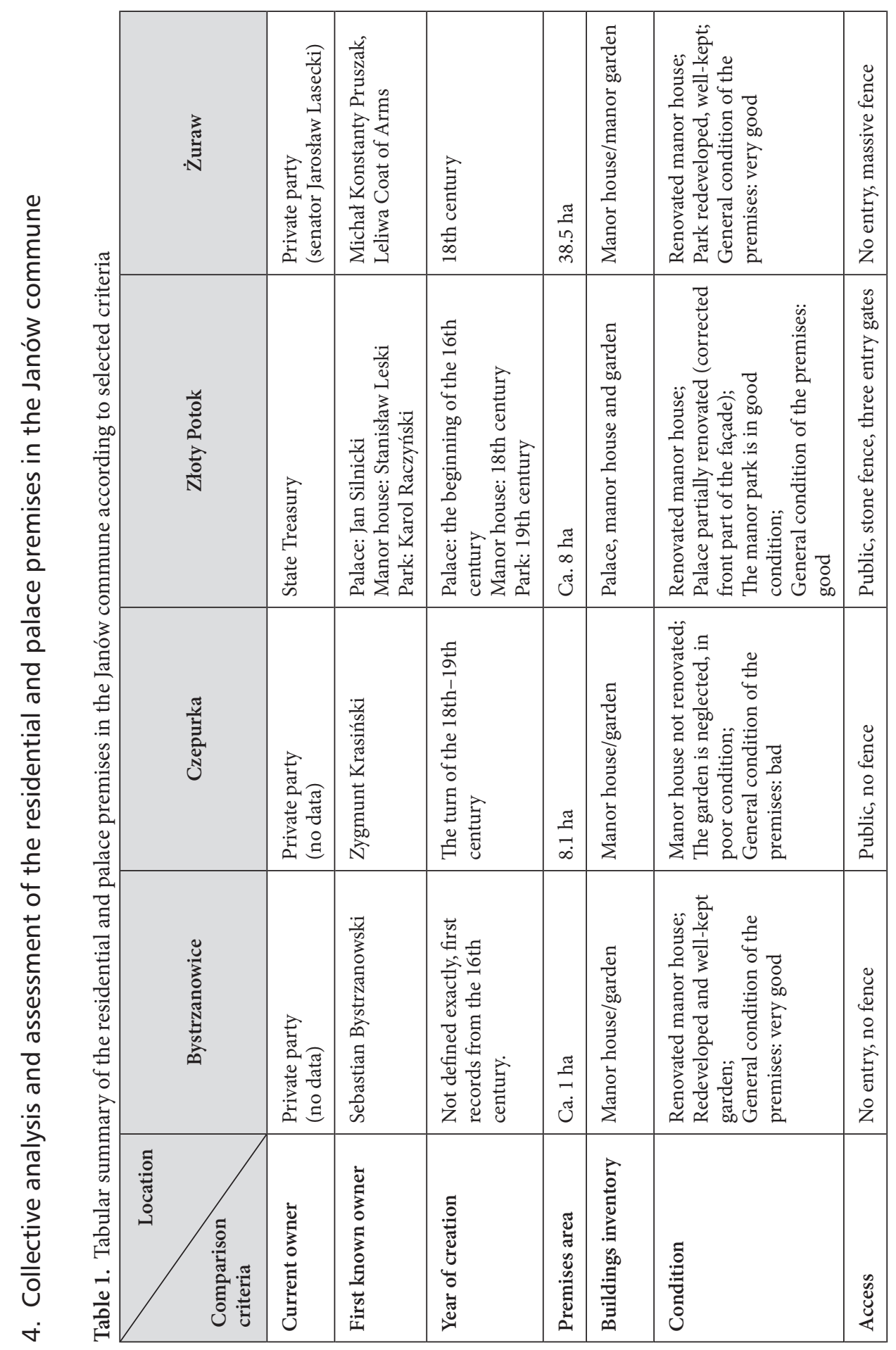




\begin{tabular}{|c|c|c|c|c|c|c|c|c|}
\hline 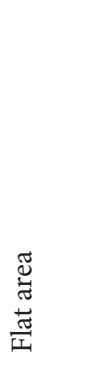 & 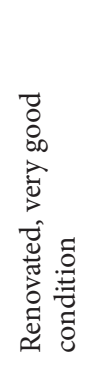 & 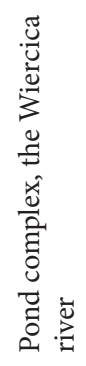 & 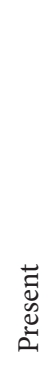 & 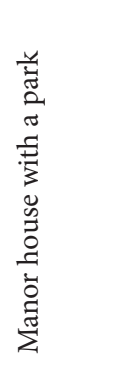 & 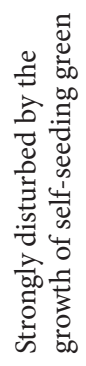 & 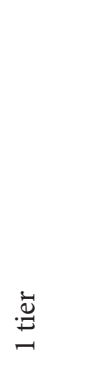 & 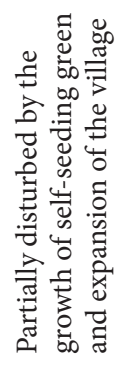 & 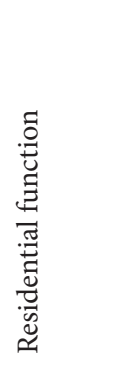 \\
\hline 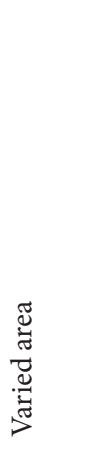 & 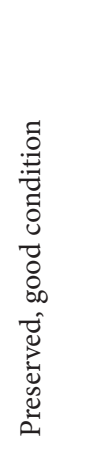 & 烒 & 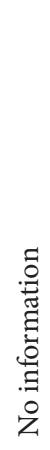 & 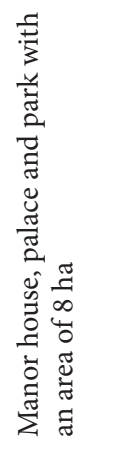 & 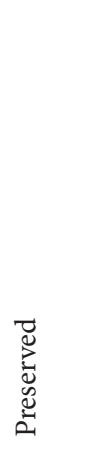 & 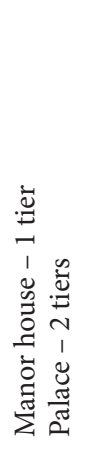 & 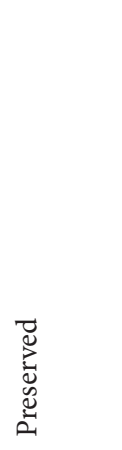 & 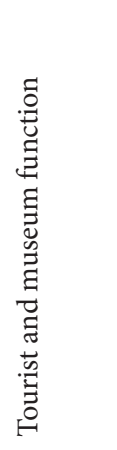 \\
\hline $\begin{array}{l}\text { J } \\
\stackrel{\Xi}{J} \\
\text { 荧 } \\
\end{array}$ & 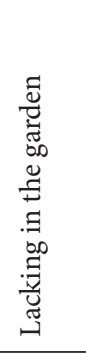 & 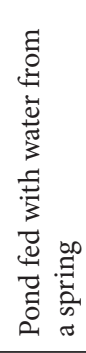 & 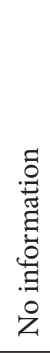 & 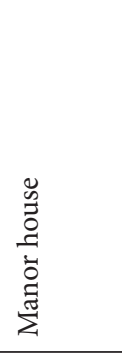 & 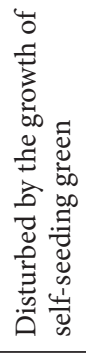 & 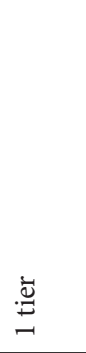 & 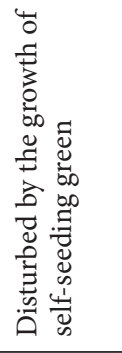 & 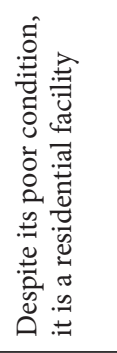 \\
\hline 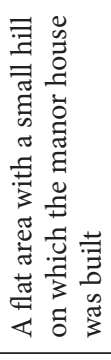 & 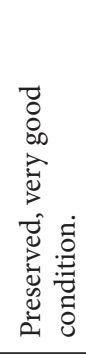 & 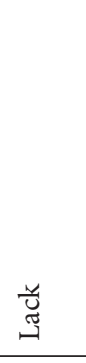 & 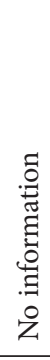 & 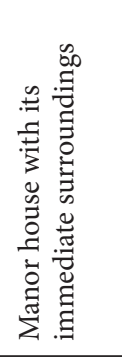 & 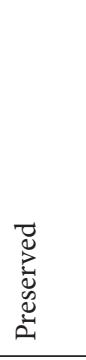 & 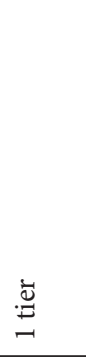 & 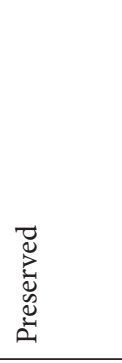 & 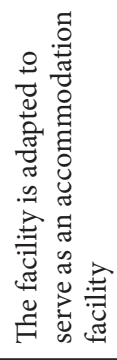 \\
\hline 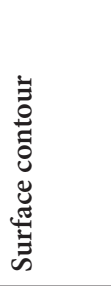 & 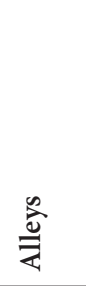 & 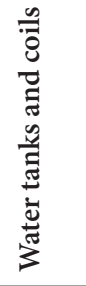 & 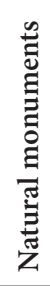 & 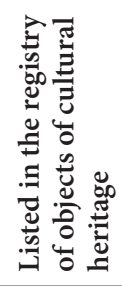 & 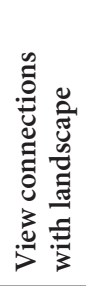 & 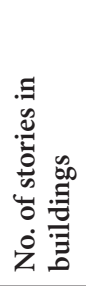 & 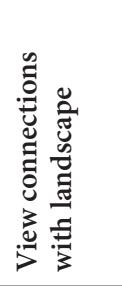 & 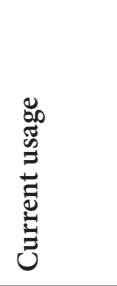 \\
\hline
\end{tabular}




\section{Conclusions}

The analysis of the arrangement status enabled the determination of the current image of four manor parks in the Janów commune [Uruszczak 2019, p. 287].

During the research, only two of the four residential and garden premises under discussion are adapted to serve tourist purposes. These are the Bystrzanowice and Złoty Potok premises. The legal status and the state of preservation of the remaining facilities do not allow them to be effectively included in the residential and garden trail in the commune. A facility such as in Czepurka, requiring urgent restoration, could 'scare tourists away', and the trail would not be popular. The commune, instead of gaining prestige, would rather be associated with the neglect of cultural heritage sites in the region. For the manor trail to exist, neglected buildings should be gradually revitalised and adapted to serve tourist purposes. On the other hand, the private premises in Żuraw, are not intended to serve tourists and remains closed to outsiders.

The gardens in question struggle with a number of problems, the most serious of which is the uncontrolled growth of self-seedings, which leads to blurring and disappearance of elements of the original composition. Depending on the regularity of maintenance work and care for greenery in manor parks, it becomes a pressing or marginal problem.

Field studies have shown that the estate in Czepurka is in the worst condition, where the original elements of the former compositional and spatial arrangement have practically not been preserved. The current owners and users of Czepurka do not care about the greenery and do not want to change it.

The managers of the manor house in Żuraw show the greatest care for greenery. The premises were revalorised.

In terms of technical condition, the manor in Bystrzanowice looks the best, while the surrounding garden itself requires analyses and supplements in terms of the legibility of the composition.

The premises in Złoty Potok are undoubtedly the most popular among tourists, despite the relatively average technical condition of the residence and its surroundings.

\section{Summary}

There are four residential and garden premises in the Janów commune. The most famous park is in Złoty Potok, leaving the remaining three 'far behind' in terms of the composition and area. Undoubtedly, all of them are worth protecting against degradation and trying to restore them to their former glory, and when rebuilding, to remember to keep their original shape and form. The Bystrzanowice residence shows that the manor house can serve not only the owner, but also serve tourist purposes perfectly. In their current state, the objects should be described in textbooks, guides, placed on maps, becoming, among other things, factors promoting the commune. 


\section{References}

Bartman E., Michałowski A., Siewniak M. 1992. Parki i ogrody zabytkowe w Polsce, stan na 1991 rok. Studia i Materiały. Ogrody 1. Zarząd Ochrony i Konserwacji Zespołów Pałacowo-Ogrodowych, Warszawa.

Bogdanowski J. 1982. Problemy genezy i systematyki polskiej sztuki ogrodowej, [w:] Architektura rezydencjonalna historycznej Małopolski. Zarząd Główny Stowarzyszenia Historyków Sztuki, Łańcut.

Borowska-Antoniewicz J., Jakubowski Z. 1980. Pałac Krasińskich w Złotym Potoku. Biuro Badań i Dokumentacji Zabytków w Częstochowie.

Ciołek G. 1978. Ogrody polskie. Arkady, Warszawa.

Kowalewski L. 1989. Przyroda parków pałacowych i dworskich na obszarze województwa częstochowskiego. Wyższa Szkoła Pedagogiczna w Częstochowie, Częstochowa.

Majer R. 1992. Dwory i pałace Ziemi Częstochowskiej. Czepurka. Gazeta Częstochowska, 55, 26-92.

Rymut K. 1967. Nazwy miejscowe północnej części dawnego województwa krakowskiego. Prace Onomastyczne Komitetu Językoznawstwa Polskiej Akademii Nauk. Zakład Narodowy im. Ossolińskich. Wydawnictwo Polskiej Akademii Nauk, Wrocław-Warszawa-Kraków.

Samek-Rejduch I., Samek J. 1979. Katalog zabytków sztuki w Polsce. T. IV. Dawne województwo katowickie, 4. Dawny powiat częstochowski. PAN, Instytut Sztuki, Warszawa.

Siwiński A. 2009. Przydrożna kronika ziemi częstochowskiej. Częstochowskie Zakłady Graficzne, Częstochowa.

Siwiński A. 2010. Średniowieczny gródek i uratowany dwór w Żurawiu. Gazeta Częstochowska, 41/42 (980/981).

Snoch B., Podobiński S. 2001. Słownik encyklopedyczny regionu częstochowskiego. T. II. Wyższa Szkoła Pedagogiczna w Częstochowie.

Uruszczak M. 2003. Czternastowieczne wieże strażnicze Jury Krakowsko-Częstochowskiej w świetle badań nad sztuką obronną w czasach Kazimierza Wielkiego. Czasopismo Prawno-Historyczne. T. LV, 2. Poznań.

Uruszczak M. 2019. Zabytkowe ogrody rezydencjonalne Jury Krakowsko-Częstochowskiej. Historia, przemiany, ocena stanu. Wydawnictwo Uniwersytetu Rolniczego w Krakowie, Kraków.

Zatoński S. 2010. Z pałacu do szkoły. 62 lata Szkoły Średniej w Złotym Potoku 1948-2010. III Zjazd Absolwentów. Złoty Potok, 12-13 czerwca 2010.

Zwoliński M. 1992. Szkice monograficzne Janowa i okolicy. Częstochowskie Zakłady Graficzne, Częstochowa.

Dr inż. Michał Uruszczak

University of Agriculture in Krakow

Department of Land Management and Landscape Architecture

ul. Balicka 253c; 10-149 Kraków

e-mail: michal.uruszczak@urk.edu.pl

ORCID: 0000-0002-3654-9869 